\title{
The Politics of Local Tax Policy-Making in Poland ${ }^{1}$
}

Paweł Swianiewicz ${ }^{2}$

\section{Abstract}

The paper answers two basic questions:

- To what extent is tax policy an important item of the local political agenda in Polish municipalities? Is it a subject of intense debates at city hall and local councils or is it accepted as a routine exercise? The results suggest that the issues related to local taxes play a relatively marginal role compared to issues such as the location of major investments. However, the importance of taxes in local debates increases in those local communities in which the tax yields collected are larger and in the case of those taxes which are paid by a wider group of tax payers.

- Who governs in local tax-policy-making? According to local provisions the proposal of tax resolution is submitted by the mayor, and the local council makes the final decision. But empirical findings suggest that the practice follows the "strong mayor" model, in which the local political leader, supporter by his staff of the financial department, is more influential than the councilors.

Those questions are answered on the basis of field research conducted in 2014 in 36 Polish municipalities. The research methods included content analysis of minutes of local council meetings, as well as face-to-face survey and semi-structured in-depth interviews with over 100 mayors, chiefs of finance departments in city halls and councilors.

\section{Key words:}

local government, local taxes, tax policies, mayor, local council.

1 The paper is based on results of the "Local Tax Policies as Instruments in Development Competition" research project. The project is funded by Narodowe Centrum Nauki (Polish National Science Centre) grant number 206427 (Contract no. UMO-2012/07/B/HS4/00453).

2 Department for Local Development and Policy, Faculty of Geography and Regional Studies, University of Warsaw, Poland. 
Polish municipal governments enjoy the limited power of tax autonomy. The national legislation defines the tax base and maximum rates of all taxes, but local councils may decide upon the local rates which are lower than the ceiling rate; they may also grant tax reliefs to some categories of tax payers. And the city mayor has the right to grant individual tax exemptions or defer the payments to be made by individual tax payers. Tax autonomy is limited to the relatively narrow category of local taxes, which provide ca. $20 \%$ of total budget revenues. The property tax is by far the most important local tax, providing about $12 \%$ of total municipal revenues. The other major local taxes are the tax on agriculture (paid by hectare of arable land, with coefficients concerning quality of soil, climate and economic conditions of the region) and tax of motor vehicles (which are levied on buses and lorries, but not on small passenger vehicles, nor motor-cycles). The remaining local taxes are of marginal importance - bringing less than $1 \%$ of total budget revenues, although they might be more important in specific cases of single municipalities - and will not be discussed further in this paper.

The rest of municipal budget revenues comes from:

- revenues from provided services, properties owned by local governments and other, minor own-source revenues

- local shares in PIT and CIT (shares are allocated to local governments "by origin" and are treated as revenues from own sources in official budget classification, although local authorities have no discretion to decide upon these revenues)

- general and specific purpose transfers to the local government budget.

\section{Research questions and hypotheses}

This paper focuses on the political process leading to the decisions on tax policies. Two basic questions are:

- To what extent is tax policy an important item of the local political agenda in Polish municipalities? Is it a subject of intense debates at city hall and local councils or is it accepted as a routine exercise?

- Who governs in local tax policy-making? What is the actual (not only formally prescribed by legal regulations) role of mayors, councilors, local bureaucrats and possibly other (societal) actors?

Revenues from local taxes provide a relatively small proportion of total budget revenues. They also constitute only a minor part of the overall tax burden carried by tax payers - both residents and businesses. Therefore in our main hypothesis 1 we expect that issues related to local tax rates, reliefs or exemptions are not among the main topics of the local public debate. 
But at the same time we expect that this generally low intensity of debates differs from one local government to another. Our detailed hypotheses refer to that variation.

Hypothesis 1.1 suggests that the higher meaning of the tax in the total budget (higher tax yield as proportion of total budget revenues), the more intense is the debate.

Even if local taxes play a relatively marginal role, the tax burden is always a sensitive political issue, and voters react in a lively manner to any suggestions of rate increases. Therefore, we do not expect the topic to be totally absent in local politics. We refer here to the classic study by Anthony Downs $(1957,73)$, who claimed that governments continue to increase their spending as long as the marginal benefit related to additional votes gained due to better public services is equal to marginal loss of votes related to increasing tax rates. There are numerous studies suggesting that voters are not consistent. Mouritzen and Winter (1992) use the phrase "naive egoists" to describe the attitude in which they demand higher public spending, but refuse to accept higher taxes (or even demand lower rates). Consequently, in our hypothesis 1.2 we expect that the larger the number is of voters that are tax payers of a given tax, the lower the tax rates are. Local governments make their tax decisions very carefully, and they are aware that a larger group of tax payers has more to say when it comes to local elections).

But who makes the crucial tax decisions on the local level? The law is very clear on that issue. The draft of tax resolution is submitted by the mayor, but the final decision is made by councilors who are free to change the mayors' proposal. How does it looks in practice? Using classic Mouritzen and Svara (2002) typology, the Polish system of executive power may be classified as a "strong mayor system". Also Heinelt and Hlepas (2006) classify Poland as a "strong executive mayor" localgovernment system. It corresponds with opinions of Polish experts, who often claim that the introduction of direct mayoral elections in 2002 made the position of the council very weak in local horizontal power relations (see, e.g., Regulski 2014). Following those observations (hypothesis 2) we expect that crucial tax decisions are shaped first of all by the mayor. We also expect a high importance of the city treasurer (head of the finance department). From the purely legal point of view, the role of treasurer is technical only - his (her) role is to implement policies as defined by the mayor and the council. But theories based on empirical studies of policy-making indicate that the reality is often different. From the principal-agent model we know about the asymmetry of information between politicians and local administrative staff, and that asymmetry influences the real impact on decisionmaking (e.g. Rees 1985; Stiglitz 1987; Epstein and O'Halloran 1999). In the case of our study, it is the head of the finance department who has more comprehensive knowledge on local revenues, and more generally on the financial situation of the 
municipality, and using this asymmetry of knowledge he (she) may have a considerable impact on eventual tax policy decisions.

But that does not mean that councilors are totally passive. They speak in tax debates, but we expect that their activity rarely results in a significant modification of the policy proposed by the mayor (in cooperation with city treasurer). We also expect that (hypothesis 3 ) councilors try to use tax debates to build their political capital. In their activeness councilors more often see themselves as representatives of voters (tax payers) than watchdogs taking care of the overall balance of the local budget.

In the next sections of this paper we test the propositions formulated above.

\section{Empirical data and research methods}

The study is based on the field research conducted in 36 municipalities located in six different regions of Poland. Data were collected between May and September 2014. The study has concentrated on relatively small local governments - the largest visited city had 29,000 residents. Five of the visited local governments had more than 15,000 residents, ten were between 10,000 and 15,000, twelve between 5,000 and 10,000 and nine were smaller than 5,000 residents. The median level of per-capita tax base in the selected sample is very close to the national average. The selection of the sample has taken into account the following criteria:

- The share of at least one of the local taxes in total budget revenues is higher than the median for the whole country.

- Local tax policies are diversified - the list of selected local governments includes both municipalities usually applying rates very close to the available maximum and local governments deciding for significantly lower taxes, numerous tax reliefs and exemptions.

- The respective local government belongs to one of various historical regions of Poland. The sample concentrates on the Lublin region (Eastern Poland), Lower Silesia (South-Western Poland), a group of municipalities in three neighbouring regions of Northern Poland and a couple of local governments in the suburban zone of the capital city Warsaw.

The main empirical material is based on the following sources:

- Local politicians (both mayors and councilors) and bureaucrats (treasurers chiefs of financial departments) were surveyed face-to-face in their offices, using a short standardized paper-based questionnaire, containing mainly closed-ended questions. Altogether, 111 questionnaires were conducted, including 46 with councilors, 34 with municipal mayors, 29 with chiefs of finance departments and 2 with other employees of local government administrations; 
- Subsequently the same respondents were interviewed in the form of semi-structured in-depth interviews in order to better understand motives behind adopted policies and mechanisms of decision-making. 32 of those interviews were transcribed, coded and used in the empirical analysis;

- An important supplementary source of information has been the analysis of the content of tax resolutions adopted by municipal councils for 2013 and 2014 as well as the minutes from council meetings, summarizing the discussion among councilors.

In two-thirds of the investigated municipalities the tax which brings the highest budget revenues is the property tax paid by legal entities, levied on their commercial properties. In two mountain tourist resorts most important is the property tax paid by physical persons. In nine rural local governments the highest revenues are brought in by the tax on agriculture. And in one of the municipalities located in the suburbs of Warsaw most significant is the tax on motor vehicles.

The share of individual taxes in total budget revenues as well as the rates of local taxes compared with the maximum rate are briefly presented in Tables 1 and 2 . They illustrate that the median values are not distant from the national average and at the same time that the selected sample is internally diversified - including local governments with different tax policies and different revenue structures.

Table 1

Percentage share of individual local taxes in total own-source revenues (without shares in PIT and CIT) (2012)

\begin{tabular}{|l|c|c|c|c|c|c|c|c|}
\hline & \multicolumn{4}{|c|}{ Selected sample } & \multicolumn{3}{c|}{ All Polish municipalities } \\
\cline { 2 - 9 } & Mean & Median & Max. & Min. & Mean & Median & Max. & Min. \\
\hline $\begin{array}{l}\text { Property } \\
\text { tax on legal } \\
\text { entities }\end{array}$ & 33.3 & 34.8 & 63.6 & 5.1 & 31.2 & 30.2 & 91.7 & 3.4 \\
\hline $\begin{array}{l}\text { Property tax } \\
\text { on physical } \\
\text { persons }\end{array}$ & 15.9 & 15.1 & 43.8 & 4.4 & 15.9 & 15.1 & 52.1 & 0.4 \\
\hline $\begin{array}{l}\text { Tax on } \\
\text { agriculture }\end{array}$ & 15.7 & 15.4 & 47.3 & 0.05 & 15.6 & 12.2 & 69.8 & 0 \\
\hline $\begin{array}{l}\text { Tax on motor } \\
\text { vehicles }\end{array}$ & 5.1 & 2.9 & 69.4 & 0.2 & 4.4 & 3.4 & 69.4 & 0 \\
\hline
\end{tabular}




\section{Table 2}

Average tax rates - revenues from local taxes as \% of available if only maximum tax rates are applied, no tax reliefs nor exemptions (2012)

\begin{tabular}{|l|c|c|c|c|c|c|c|c|}
\hline & \multicolumn{4}{|c|}{ Selected sample } & \multicolumn{3}{c|}{ All Polish municipalities } \\
\cline { 2 - 9 } & Mean & Median & Max. & Min. & Mean & Median & Max. & Min. \\
\hline $\begin{array}{l}\text { Property } \\
\text { tax on legal } \\
\text { entities }\end{array}$ & 81.8 & 87.4 & 99.8 & 42.9 & 88.5 & 90.4 & 100 & 27.4 \\
\hline $\begin{array}{l}\text { Property tax } \\
\text { on physical } \\
\text { persons }\end{array}$ & 74.1 & 77.4 & 98.2 & 29.9 & 73.4 & 73.4 & 100 & 22.3 \\
\hline $\begin{array}{l}\text { Tax on } \\
\text { agriculture }\end{array}$ & 75.6 & 76.6 & 100 & 41.3 & 73.1 & 70.9 & 100 & 9.3 \\
\hline $\begin{array}{l}\text { Tax on motor } \\
\text { vehicles }\end{array}$ & 62.4 & 61.5 & 100 & 22.1 & 63.2 & 61.6 & 100 & 22.1 \\
\hline
\end{tabular}

\section{The role of tax policies in local public debates}

In the light of conducted interviews, local taxes are not among the issues raising lively public debates. The main issues discussed in village meetings are usually local roads. As one of the councilors from a Lublin region municipality told us, people in public meetings say that we pay taxes and we demand better roads. The specific taste of that quotation is related to the fact that residents of that particular local government have been released from paying the tax levied on their housing properties. Limited interest in local taxes is not surprising, taking into account their limited role in budget revenues and smaller - compared to other (national) taxes - tax burden for payers. The quotation from one of the councilors talking about an owner of a large farm (employing several hundred workers) is very characteristic in this context:

Rates of the tax on agriculture are not important for him. He has never talked to councilors on that issue. I suspect that this tax is just a small drop in an ocean of what he needs to pay [in other taxes and duties]. In general the tax on agriculture is one of the smallest burdens we carry. All others: energy, fuel, raw materials for agriculture production - here are significant amounts involved. But the local tax is just a peanut.

Those individual observations are confirmed by survey results presented in Figure 1 . The intensity of debate is measured on a scale from 1 to 4 , where 1 means lack of any debate, and 4 represents very intense debate. In none of the cases presented in Figure 1 does the mean score reach the medium score (2.5). The issue of local taxes was only sporadically present in the 2010 election campaign. Also in 
2014 respondents expected a similarly low importance of the issue (our survey was conducted a few months before the 2014 local elections). The tax issues are a bit more present during meetings with local authorities, but also in that case they are rather a supplement to other hot issues, rather than the main topic of a discussion.

But one may notice that the intensity of debates depends on which of the taxes we are talking about. The tax on agriculture and the tax on commercial properties bring a bit more emotions, while the low numbers in Poland of people who pay taxes on motor vehicles or housing properties are the reasons that they are very rarely debated.

As we expected in our hypothesis 1.1, the intensity of debates is higher in those municipalities in which the tax brings a larger proportion of local revenues. But interestingly, this rule concerns commercial properties and the tax on agriculture but is not seen in discussions on taxing housing properties (see Table 3).

Even more interesting is the fact that in the case of housing properties and tax on motor vehicles there is no such relationship - perhaps because the importance of those taxes, both for the typical voter and for local authorities, is minimal. In the case of the tax on agriculture, the relationship mentioned above is also reflected in the correlation with the local government size - the tax raises more interest in the smallest municipalities (see Figure 2), in which the tax is relatively more important for the local budgets.

Figure 1

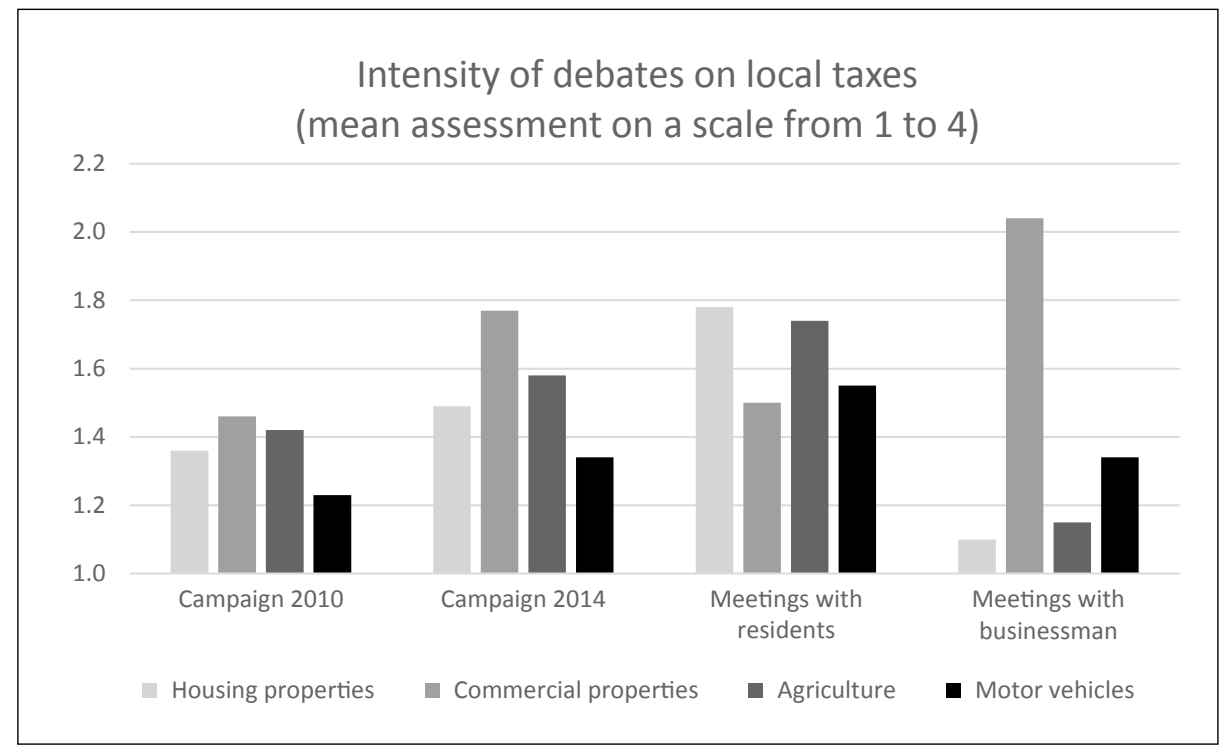

Source: survey of local politicians and staff $(\mathrm{N}=111)$ 


\section{Table 3}

Relationship between share of the tax in total revenues and intensity of debates on tax policies (correlation coefficients).

\begin{tabular}{|l|c|c|c|c|}
\hline & $\begin{array}{c}\text { Discussions } \\
\text { in council } \\
\text { committees }\end{array}$ & $\begin{array}{c}\text { Discussions in } \\
\text { council plenary } \\
\text { sessions }\end{array}$ & $\begin{array}{c}\text { Debates in } \\
\text { meetings with } \\
\text { residents/local } \\
\text { businessman }\end{array}$ & $\begin{array}{c}\text { Expected } \\
\text { debate during } \\
\text { 2014 election } \\
\text { campaign }\end{array}$ \\
\hline $\begin{array}{l}\text { Tax on } \\
\text { commercial } \\
\text { properties }\end{array}$ & $+0.19 * 1$ & $+0.24 *$ & \\
\hline $\begin{array}{l}\text { Tax on } \\
\text { agriculture }\end{array}$ & $+0.56 * * *$ & $+0.43 * * *$ & $+0.48^{* * *}$ & $+0.36 * * *$ \\
\hline
\end{tabular}

Figure 2

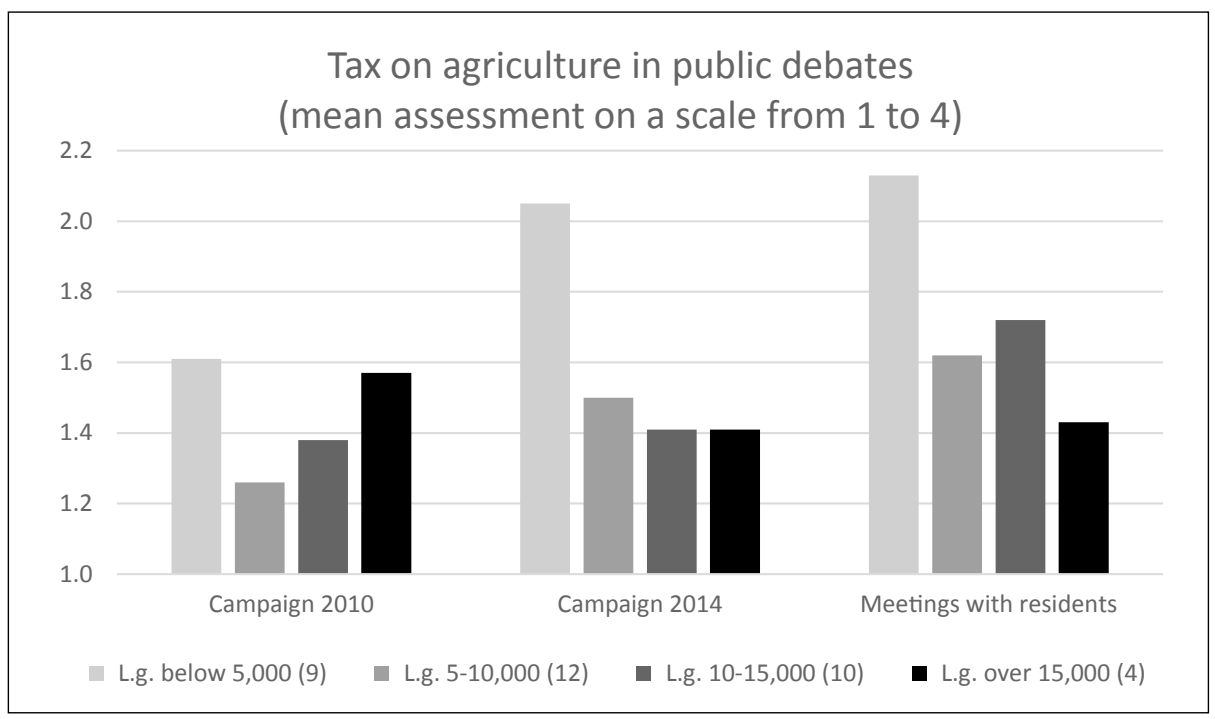

Source: survey of local politicians and staff $(\mathrm{N}=111)$

That does not mean that there are no public debates on local taxes at all. But discussions are usually limited to the narrow circle of participants - usually the most interested owners of local business companies. That rule is the most visible in the case of the tax on motor vehicles. It is very characteristic that for the question on which tax raises the most lively discussions in a couple of local governments we got the answer that it was the tax on vehicles. But during the in-depth interview we

3 Here and further in the text: *** - correlation significant on the 0.001 level, $* *$ - significant on the 0.01 level, * - significant on the 0.05 level. Blank spaces in the table mean no statistically significant correlation. 
learnt that although discussion was very lively, it was limited to a very narrow group, consisting of sometimes just two or sometimes about a dozen interested businessmen. It is worth remembering that their business activity is conducted on a national (sometimes even European) scale, and the municipality is just a place where they register their cars. Those discussions sometimes take a very drastic form. In the minutes from a council meeting in one of the local governments in Lower Silesia we read that the businessmen present during the meeting demanded that the mayor propose lower tax rates, and when the mayor refused they left the room slamming the door. The local treasurer told us about that event in the following way:

The tax on motor vehicles really got under our skin last year. There was a letter of protest from 30 or 40 people, demanding to lower or even to abolish the tax, which is too high. During the council meeting they were not polite, including slamming the door, swearing... Businessman came to the session in their expensive cars, but fought to pay lower taxes.

\section{Is there a danger that they may move their cars to another municipality, where tax rates are lower?}

They say so, but they never do. No, I am not afraid of it.

Also in relationship to other taxes, during the conducted interviews we learnt about intense discussions, although usually leading to a sort of compromise solution. The typical pattern is that the mayor and the city treasurer try to increase the tax rate, and tax payers demand keeping the low rates. Interestingly, councilors usually adopt the position of tax payers, leaving the role of budget guards to the mayor and his/her administration (which refers to our hypothesis 3 ). The quotation from the interview with one of the councilors is very characteristic here:

We try to meet farmers and to discuss. To look for a consensual solution. The mayor gives in a bit - ok, make it a bit lower. We [councilors] also try to give in and agree for a rate that is a bit higher. Farmers as well: ok, let's agree on a bit higher than what we wanted. And we meet the mayor half way. On the farmers' faces we see that they are not totally satisfied, but they are happy that it is not going up as much as they were afraid it would initially.

It seems that local taxes raise high emotions in a few situations only. First, when there are changes in legislation (or in interpretation of existing law), which cause the tax to be calculated differently from what the way it was until then. The recent examples are the legal changes in the tax on agriculture, which used to be dependent on the average price of crops during the last 3 quarters, but the base 
was extended to the average from the previous 11 quarters. ${ }^{4}$ The intention was to stabilize the tax base, making it less vulnerable to cyclical fluctuations of prices, but when the change was introduced it caused an increase of the maximum rates, which was - according to the opinions of several mayors - met by hostile reactions from farmers. The change in the law on the property tax, which increased the tax burden on car garages, falls in the same category.

The second category is related to specific circumstances which make the financial situation of tax payers more difficult, but it is not reflected in the tax burden. In a couple of mountain tourist resorts we met such a situation in the context of "bad seasons" (with no snow during the winter), which has no direct impact on the level of property tax to be paid.

The third category, which we saw first of all in municipalities with very low tax rates so far, concerns the situation in which local authorities plan to change previous tax policies by increasing tax rates, while tax payers treat it as a plot against their "acquired rights". In several municipalities of the Lublin region this occurred several years ago when it was decided that residents would not pay taxes on their housing properties. Changing that decision is extremely difficult, even if local authorities are convinced that it was the wrong decision. This claim may be supported by the following quotations:

There would be an incredible scream from residents if we taxed their homes. The mayor does not want even to listen to such an idea (treasurer of a rural local government).

I have tried three times to do it [to increase the tax on agriculture]. But most of the residents are farmers and they say: "Why do you want to do it? You will not get an awful lot of money, but you will have trouble." I have calculated carefully. The increase of revenues would not be dramatic, indeed. So we left it as it was. Although I think we should change it, it would be fair (mayor of a small town).

We have tax relief for the tax on housing properties. It has always been like this, since I came to my office. So far we did not need to use this source, but I think it will change very soon. Especially taking into account that costs of schools are rising... The best idea would be to make the change simultaneously in several neighbouring local governments. It would help to limit protests of citizens (mayor of a rural local government).

The latter quotation confirms the existence of the yardstick competition which was described in an earlier study (Swianiewicz and Łukomska 2014). In the literal

4 As was explained earlier the tax on agriculture is levied depending on the number of hectares. But the actual amount to be paid per hectare is also dependent on the market price of rye. 
sense there is no yardstick competition in the described case, but rather a collusion (or attempt at collusion) of several local governments. But demand for such common action from several local governments arises from the understanding of yardstick-competition mechanisms.

In spite of the fact that local taxes are not hot political issues, politicians are afraid of bringing tax rates onto the agenda. In a couple of municipalities in the Lublin region we heard of avoiding rate changes especially before local elections. But nation-wide data do not confirm the statistical impact of the political cycle on local tax rates (see Swianiewicz and Łukomska 2015), although the cycle is clearly visible in some other elements of local policies - such as the budget surplus (Swianiewicz 2011) or changes in local schools' network (Herczyński and Sobotka 2013).

\section{Mechanisms of decision-making}

In this section we analyze the process of decision-making within institutions of local authorities. We are interested in internal debates within the city hall. Which stage of debates is the most important? What is the role of discussions in the narrow group of leaders within local administration? Or perhaps debates of the Council Committee for local-government finance are more important? Or maybe what happens during the plenary session of the whole council is of crucial importance? We are also interested in who has in fact the largest impact on the final shape of the tax resolution? Are there councilors, as is suggested by the literal formulation of the Municipal Government Law? Or perhaps the mayor, who has the sole right to submit the draft of the resolution to the council? Or maybe the city treasurer and his/her staff, who have an informal impact due to their professional knowledge and analytical skills? (see hypothesis 2). Such a situation would differ from that assumed by the Law but would go along with several political theories, especially those originating in public choice. Or, finally - may other lobbying groups have a decisive impact, as is suggested by the elitist theory of community power or by more comprehensive regime theory (Hunter 1953, Stone 1989)? There might be, for example, the influence of businessmen or investors whom the local government wants to attract (or to keep in the locality). Trying to answer those questions we use, first of all, the reputational method, which is well grounded in community power studies 5 . A questionnaire and in-depth interviews with local political actors are supplemented with an analysis of documents, such as minutes of council meetings.

\subsection{Local taxes - the role of councilors}

In the common opinion of our respondents, the most intense debates are carried out during the meetings of the Finance Committee of the council. Discussions on the plenary session sometimes have the character of a performance for local media

5 At least since the classic Community Power Structure study by Floyd Hunter (1953). 
and citizens, while the final result of the debate is determined well in advance. The least intense are discussions within local administration, before the draft resolution is sent to the council (see also Figure 3 and Table 4). But in none of the cases the debates are really hot - the mean assessment of their intensity is always below 2.5 , which is the average in our 1-4 scale. The most discussed tax is usually that on commercial properties, followed by the tax on agriculture, but the differences between the four taxes are not very big.

There are clear relationships explaining the variation in the intensity of the debates. They are especially strong in the case of the tax on agriculture. As we expected in our hypothesis 1.1, the intensity and temperature of debates are high especially in those municipalities in which the tax provides a significant proportion of the total revenues (see also Table 3 ).

\section{Figure 3}

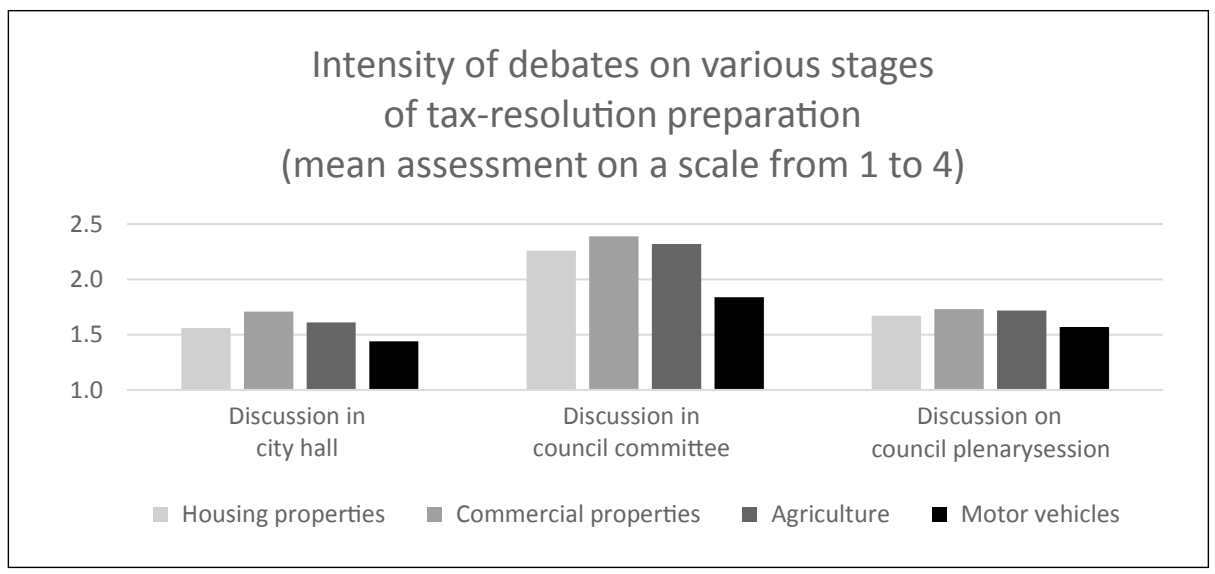

Discussions are also negatively correlated with tax rates (i.e. they are more intense in localities which apply lower rates - correlations with discussions by the Committee $-0.401^{* * *}$, and in plenary session $-0.293^{* * *}$ ). It must not be interpreted in a way that more debates lead to lower tax rates. It is more important that in communities in which the tax on agriculture has only marginal meaning applied rates are usually close to the maximum, and they do not raise any discussions. In fact, this relationship is just an indirect consequence of the role of the tax yields in the local budget (indeed, correlation between rate of agriculture tax and its share in total budget revenues is significant and negative $-0.596^{* * *}$ ). This, a contrario, confirms our hypothesis 1.2. 


\section{Table 4}

Frequency of assessing debate on local taxes as "intense" (answer 4 on a scale from 1 to 4 )

\begin{tabular}{|l|c|c|c|}
\hline & $\begin{array}{c}\text { Debates in } \\
\text { city hall }\end{array}$ & $\begin{array}{c}\text { Debates in } \\
\text { the Finance } \\
\text { Committee }\end{array}$ & $\begin{array}{c}\text { Debates in council } \\
\text { plenary session }\end{array}$ \\
\hline Tax on commercial properties & $5 \%$ & $15 \%$ & $7 \%$ \\
\hline Tax on housing properties & $1 \%$ & $16 \%$ & $10 \%$ \\
\hline Tax on agriculture & $2 \%$ & $21 \%$ & $10 \%$ \\
\hline Tax on motor vehicles & $2 \%$ & $6 \%$ & $7 \%$ \\
\hline
\end{tabular}

But even in municipalities in which discussions are more intense, the draft submitted by the mayor often remains unchanged. However, there are numerous questions asked by councilors; their typical content will be discussed later in the paper.

The changes proposed most frequently by councilors in draft resolutions suggest lowering tax rates. As was mentioned above, councilors perceive themselves as representatives of citizens groups (their voters) more than guardians of the municipal financial situation. But sporadically, there are also suggestions going in the opposite direction. In that case, however, councilors usually suggest higher tax burden for tax payers who are not their voters:

Recently the Committee has suggested a change [increase of the tax rate] in my draft proposal on the property tax levied on weekend homes. The council accepted that suggestion. I was not convinced, but I did not protest. I thought that a lower tax rate on second homes may increase our tourist attractiveness. But on the other hand, I hope that we have not increased the tax to the extent which would result in scaring away those who have already invested here (mayor of a rural local government in the Lublin region).

Reading the minutes of council meetings gives us an even better idea of the intensity of debates and their final outcome. In the case of the tax on agriculture and the tax on motor vehicles it often happens that there is no debate at all. The new resolution on tax rates is not adopted, and in such a case the rates from the previous year are still valid. Figure 4 shows how often this happens. In the case of the tax on agriculture no new resolution was adopted in nearly $1 / 3$ of all investigated local governments, and this was even more common in the case of the tax on motor vehicles. Interestingly, there is a strong variation among three major regions in which we conducted our field research. 
Figure 4

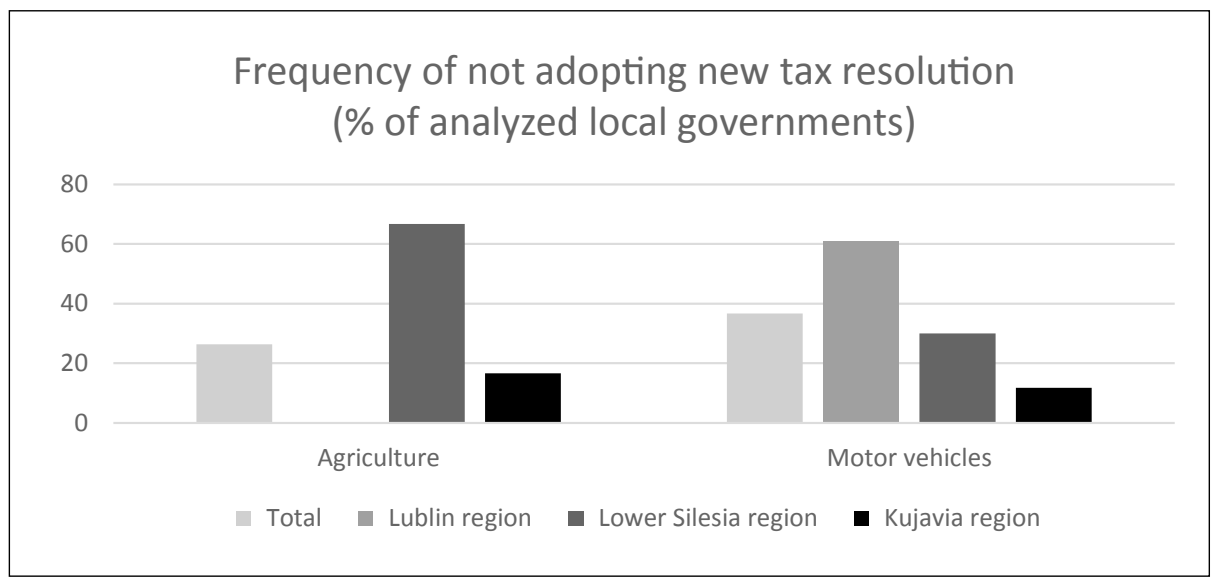

There have been no new resolutions on the tax on agriculture in $2 / 3$ of the municipalities in Lower Silesia, but we have not found a single case in the Lublin region. The difference reflects the economic structure of both regions - the Lublin region is predominantly rural with a dominance of traditional family farms. In such communities agriculture tax payers dominate among all voters, tax yields are much more significant, and the tax is an issue of more intense debates than in Lower Silesia. In the case of the tax on motor vehicles the variation is almost opposite. There was no new tax resolution in $2 / 3$ of the Lublin-region municipalities, but in only $1 / 3$ in Lower Silesia and $1 / 10$ in the Kujavia region. ${ }^{6}$ Also this variation reflects the economic structure of the researched regions - more diversified, with a larger share of non-agriculture companies in Western Poland, and more traditionally rural, with a lower number of non-agriculture businesses in the Eastern part of the country (including the Lublin region).

On the basis of reading the minutes we assessed the intensity of debates on tax issues. The discussion has been assessed on a scale from 0 to 3 , where 0 means approval of the draft with no discussion, 1 - minimal discussion (e.g. one or two interventions of councilors asking for explanations) concluded by the adoption of the original draft, 2 - not very intense discussion, but leading to amendments in the original draft proposal, or long and emotional debate but with no eventual changes in the draft, 3 - intense debate concluded by changes in the draft submitted by the mayor. The summary of that analysis is presented in Figure 5. As is clear in Figure 5,

6 To be precise our research was conducted in 12 local governments located close to the border of three regions: Kujavia, Pomerania and Warmia \& Mazury. Since the largest part of that group is located in the Kujavia region, to simplify the picture, we use the name of that region to describe the whole territorial cluster. 
the most intense discussions usually concern property tax and the least intense ones occur in the case of the tax on motor vehicles.

Table 5 tells us that even if debates are emotional and long, changes in the submitted draft proposal are rare. We have not noted a single case of such a change in the tax on motor vehicles. In the case of the tax on agriculture and the property tax we noted just 4 changes within two years in 36 researched municipalities. This provides more support for the claim regarding the strong political position of the city mayor in the politics of local taxation (hypothesis 2 ).

Figure 5

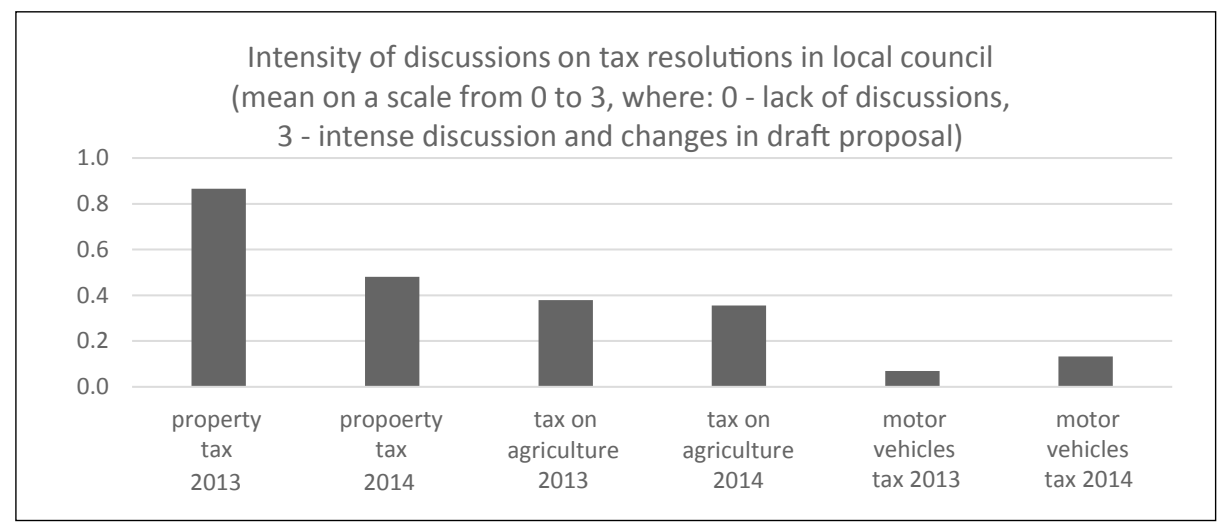

Table 5

Number of changes introduced during the council meeting to draft resolutions on the rates of local taxes (data from 36 researched local governments)

\begin{tabular}{|c|c|c|c|}
\hline & Property tax & Tax on agriculture & Tax on motor vehicles \\
\hline 2013 & 3 & 2 & 0 \\
\hline 2014 & 1 & 2 & 0 \\
\hline
\end{tabular}

One more measure of the intensity of the tax debate is the final result of voting on tax resolutions. As we see in Figure 6, most council resolutions are unanimous or with a maximum of 1-2 votes against or abstaining. This was the case with ca. $2 / 3$ of all checked council resolutions concerning the property tax, $80 \%$ related to the tax on agriculture and over $90 \%$ related to the tax on motor vehicles. Voting with minimal majority, i.e. in the environment of a sharp conflict, has happened sporadically only. During the last two years in all 36 researched local governments we found such a clear cleavage in the cases of only 5 resolutions related to the property tax, 3 in the case of the tax on agriculture and only once in the tax on motor vehicles. 
Figure 6

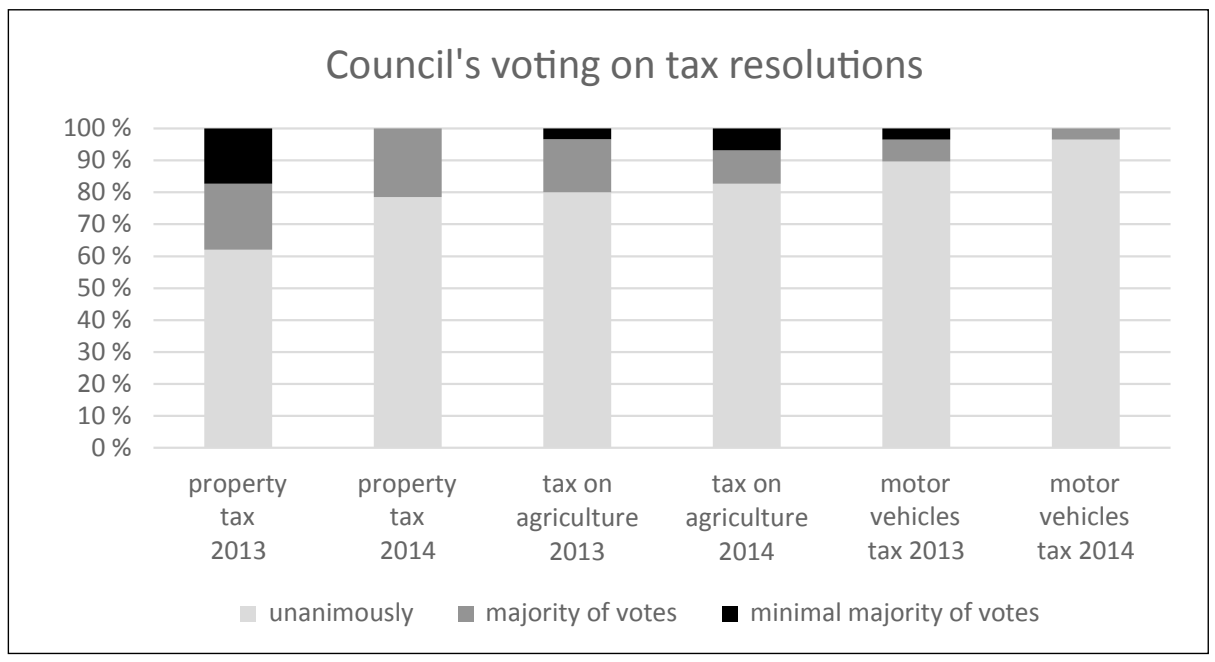

But even the lack of changes in the submitted draft resolutions and the lack of intense debates do not mean that the role of councilors is negligible and that the mayor has total freedom of shaping the tax policy according to his (her) own will. The sole awareness that councilors have to approve the mayor's proposal often causes some sort of self-limitation of the ideas that are considered.

In the case of the property tax discussions are most intense and voting most frequently not unanimous in the Lower Silesia region, in which this tax brings the highest share of total budget revenues. In Lower Silesia the mean share of the property tax in the budget is $20 \%$, while in the Kujavia region it is $12 \%$ and in Lublin just $10 \%$. In the case of other taxes the differences among regions are minimal. The quotation from one Lublin-region chief of finance department provides a good illustration of the typical relationship between the mayor and the council:

usually there is no change in the submitted draft, councilors approve what we suggest. We try to suggest only modest changes, the budget cannot change in a radical way. Local taxes is a topic which does not like revolutions, if we do not propose fast changes, then everything is ok during the council meeting.

There are a couple of typical features found in many council debates on local taxes:

1. In several local governments the rates applied in neighbouring municipalities are an important point of reference (see also the discussion in Swianiewicz and Łukomska 2014). 
2. Decisions on the rates of local taxes have to be planned in the perspective of a few years. It is usually very difficult to withdraw from reliefs which had been granted earlier, and this difficulty is very well realized by mayors and city treasurers. But according to our respondents it is equally important that the modest increase of rates (which would at least follow the inflation rate) be regularly implemented year by year. Even a one-year break in this trend is very difficult to correct later. One of the councilors characterized that rule in the following way:

There used to be no change in tax rates for a few years, and then in 2012 the mayor suggested a $40 \%$ increase. We councilors clearly demanded that in the future the pace of changes should be stable, so local businesses can plan their costs with more certainty, and we can more clearly assess what benefits we gain from the budget increase following the change in tax rates.

The treasurer of one of the Lower Silesian municipalities refers to a similar context to demonstrate the learning loop in the behaviour of councilors during their 2010-2014 term:

In 2014 the situation was as follows: for housing properties the maximum rate was 0.74 PLN per square meter. In our municipality the 2013 rate was $0.70 \mathrm{PLN}$, and the mayor suggested to keep the rate identical for 2014. But councilors came to the conclusion that it was better to increase the rate by even 0.01 PLN each year, so residents did not feel a shock if there was a higher increase after a couple of years. In fact they needed three years of their term to come to this conclusion. And to realize that they can suggest their own change or policy.

3. The above quotation indicates one more issue: councilors whose approval is requested for the increase of tax rates ask about the concrete allocation planned for extra revenues. Usually they want to hear about new investments which may be funded by extra money.

Before voting on tax resolution we stress that tax rates are one issue, but we also want to know what we get for it, how the mayor may seduce us. If we agree with the mayor's suggestion on tax rates, then we will get this and that. There have to be new investments which are attractive for the local community, in that case it is easier accept higher taxes... (councilor in the Pomerania region).

Another argument which is often convincing for councilors is the requirement to mobilize own matching funds for the grant from EU structural funds.

Such situations might be described by a typical sequence of actions. First, the mayor suggests a tax increase. Councilors - who see themselves (as in our hy- 
pothesis 3) more as voters representatives than as watch-dogs of the balanced budget - refuse. At the same time they suggest that they would be inclined to approve the new rates if they hear a strong argument in the form of concrete direct benefit, which they could show to their voters.

It demonstrates that councilors often regard changing the tax rate as an issue of marginal gain (or marginal loss). In the ideal world the optimal rate is set on a level on which the marginal cost for tax payer is equal to the marginal gain from additional resources collected by the local budget. Of course most councilors do not conduct such an analysis in a conscious way (and definitely do not use these terms originating from game theory). But the local political debate on taxes may be interpreted through the marginal costs/benefit analysis.

4. But councilors do not always behave like representatives of the "median voter" as described by Downs' (1957) theory. Sometimes they seem to represent the interests of the "median councilor". In the opinion of numerous mayors and treasurers, councilors deciding on local taxes often take into account first of all the financial consequences for themselves. This claim may be illustrated by the following quotations:

Councilors calculate the draft resolution, check their own tax burden. And if they do not like something, then they speak. But they pretend to speak on the behalf of citizens, not just representing their own interest (treasurer from the Lower Silesia region).

Tax payers decide for themselves - look, 10 out 15 councilors are farmers and they vote on the tax on agriculture (mayor in the Kujavia region).

There are many farmers among councilors. And once we discuss the tax on agriculture, then they become active, they try to argue that rates should be lower (councilor in the Kujavia region).

5. Results of voting are often determined by political cleavages in the council (not necessarily partisan cleavages - the presence of national political parties is rare on a municipal level). Councilors from the group which supports the mayor vote as he wishes. So if they have a majority in the council, the result is predetermined.

Councilors are mostly from the Mayor's local committee, they would vote following his suggestions (councilor, Lower Silesia region).

How has the Mayor convinced councilors to vote for the resolution? He has not - he just has a majority in the council (councilor from the Kujavia region). 
6. The argument which is referred to very often when the mayor or treasurer opposes the councilors' tendency to reduce the tax rates is that the change would imply a reduction of the equalization grant received from the central government. During our field research we have not found the respondent who would be able to explain the mechanism of such a reduction in detail. They usually pointed out that "the mechanism is very complicated", but that "it is common knowledge, everyone knows that it is in that way". The point is that such an opinion has no support, neither in legal regulations nor in the practice of the equalization-grant allocation. The Law decides that the equalization grant is neutral towards the actual policy of the local government, i.e. the amount of the grant itself is the same whether the tax rates are on the maximal level or they are reduced. Anyway, it is fascinating that the myth of punishing local governments for their tax decisions is so wide-spread among local-government politicians and officials. It indirectly indicates the low level of understanding of the mechanisms of inter-governmental finance.

\subsection{Local taxes - who governs?}

In the common opinion of all groups of our respondents it is the local mayor who is the most influential in shaping local tax decisions. The city treasurer is second in this ranking of importance, and the impact of councilors is perceived as less important. Other actors, outside of the formal structures of local-government institutions, have been indicated very rarely. This does not mean that they never play a role: In one of the visited municipalities we discovered that the new, reduced rate in the tax on motor vehicles was in fact agreed after confidential negotiations with a big company, ready to register several hundred of its cars in this municipality if the rates were sufficiently low. Dafflon and Rossi (2004) argue that such negotiations might be identified with a specific type of tax competition. But these are exceptional cases which cannot change the general picture.

The summary of answers for relevant questions is presented in Figure 7. Although all major groups of respondents agree in their opinions about the dominant position of the mayor, there are also interesting differences among them. Councilors estimate their own impact higher than other groups. They also assess the importance of the local treasurer higher, while they see the impact of the mayor to be a bit less significant than in the perception of the other groups. The reason for that difference is perhaps in the fact that it is the treasurer who usually presents the draft proposal of the tax resolution to the council, and it is the treasurer who is the most active in the debate with councilors. The mayor often keeps silent, so his (her) role is not as visible. It may produce the biased impression regarding who the real author is of the concept of tax policy expressed by the draft of the resolution.

There are also the following results related to the variation of the role of the main groups of actors in different local governments: 
- Councilors are more active and have a larger influence in local governments in which the tax on agriculture provides a larger share of total budget revenues (correlation $+0.331^{\star * *}$ ). The role of the lobbying of other groups (first of all farmers) is indicated more often in the same group of municipalities.

- In the case of the tax on motor vehicles the perceived role of the treasurer is lower in local governments in which revenues from this tax are higher (correlation $-0.258^{* *}$ ). In such communities in which the number of tax payers is larger, the decision on the tax is no longer purely technical, but it becomes more political. In such circumstances the debates and decisions involve local politicians (mayors, councilors) to a larger extent. It is another indirect confirmation of our hypothesis 1.1 suggesting that the intensity of debates is larger in local governments in which the tax revenues are more important.

\section{Figure 7}

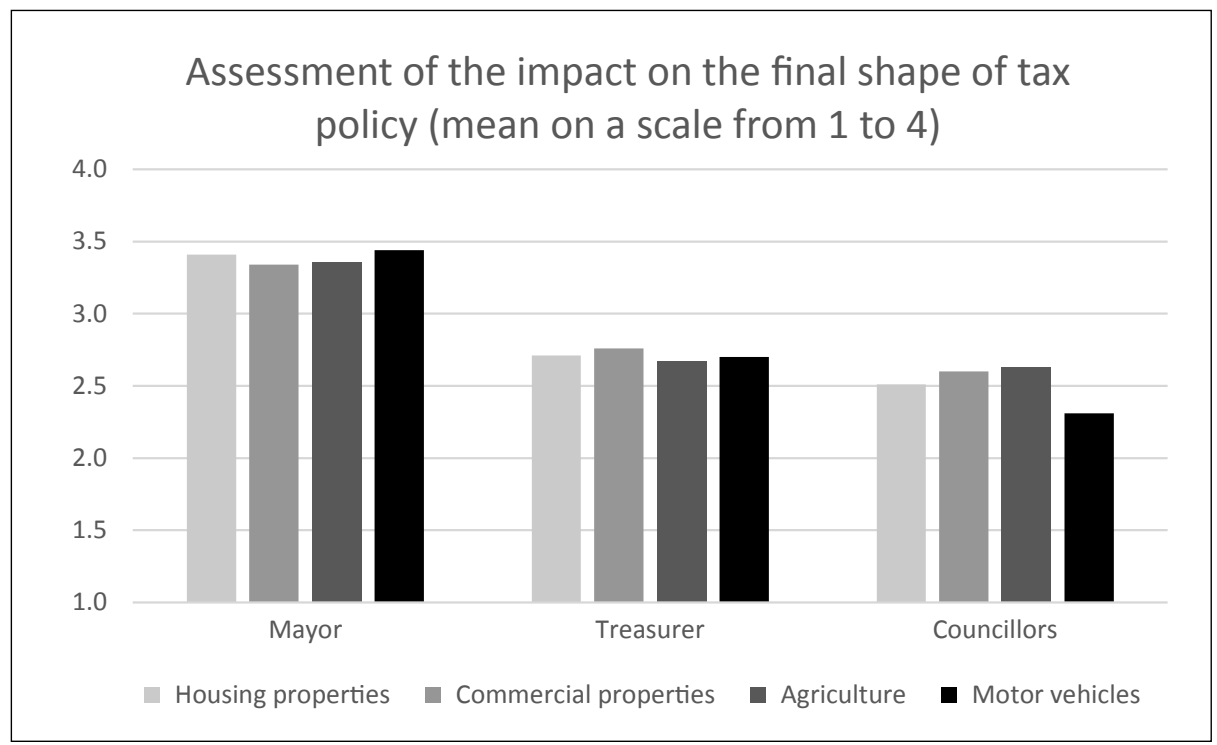

The opinion on their dominant role is also shared by most mayors themselves. Moreover, they treat this situation as something natural and desired. One of them expressed to us a critical opinion about our survey using the following argument:

Your questions make no sense. What debate in the city hall? Tax policy is my responsibility, and I am not going to discuss it with anyone, with any employee of the city hall (mayor).

Sometimes they admit that they try to manipulate councilors' behaviour: 
Usually there are no discussions during the council's plenary session. To some extent I am to be blamed. Once one of the councilors asked the question. I asked him several questions to clarify his points, and the effect was that there was an impression that he was not competent and that his question made no sense. So now other councilors are afraid to say anything loudly (mayor of a rural local government).

The mayor should be elected by all citizens, and the mayor should elect the council. Because the council should help the mayor... it is difficult to talk about being a good mayor, if there is an opposition in the council... rates of local taxes rarely remain on the level which I suggest. Nor are they ever increased by councilors. Therefore I have to propose high rates, and I know that councilors will try to reduce them... I can also make individual tax decisions related to individual tax payers. And it is very good, since these are decisions which I do not need to explain to the council and wait for their approval (mayor of a rural local government).

\section{Conclusions}

The results of the investigation confirm most of our initial expectations. The most important actor in local tax-policy-making is usually the mayor. Also city treasurers seem to play a more important role than municipal councilors (hypothesis 2).

The role of local taxes in local political debate is usually very limited (hypothesis 1). It is an issue which is discussed less often than several others (especially those connected with investment policies) during election campaigns or meetings with local residents. It rarely happens that discussion on local taxes attracts a large audience to city council meetings, although we have also noted exceptions to this rule. This does not mean that residents remain uninterested at all. They usually react nervously to the increase of tax rates, especially when the change is more than incremental. On the other hand, local authorities understand that limitation and take it into account in their very careful decisions, so to avoid an open conflict on tax issues. An important part of local decision-making is the comparison of tax rates with neighbouring municipalities, which takes the form of yardstick competition.

As was expected in hypothesis 1.1, the intensity of debates is higher in local governments where the local tax brings tax yields which are more important for the local budget. In the case of the tax on agriculture it has also been demonstrated that a large number of tax payers correlates with lower tax rates. However, that proof is indirect only, and the issue requires more detailed studies in the future. Also, as expected in hypothesis 1.2, we found support for the claim that the larger the number of tax payers is, the less likely it is that the tax rate is set on a maximum level. 
In our hypothesis 3 we expected that most councilors identified themselves more with the role of voters' representatives than with the role of watch-dogs of the balanced budget. It is related to their attempts to build and maintain political capital before the next elections. Most of opinions collected during the interviews confirm that expectation, although in some opinions councilors' behaviour is driven by their own interests. Those two interpretations are in fact inter-linked. The social composition of the council often reflects the social structure of the local community. For example in typical rural local governments most of the councilors are farmers. Their own interests related to rates of local taxes are not different from the interests of the majority of residents.

Both economic factors (such as taking care of local budget revenues, developing local businesses, attracting new investments) and political factors (possible reactions of voters) are taken into account in local tax-policy-making. But in both cases the importance of these considerations is limited, since it is related to revenues which provide a relatively minor proportion of the total budget revenues. Nor are they the major part of the tax burden for local residents and businessman. Therefore it is doubtful if we may talk about a separate phenomenon which might be called the politics of local taxation. We should rather talk about the tax dimension of the broader phenomenon of local politics.

\section{References}

Dafflon B. and S. Rossi. 2004. "Tax Competition between Subnational Governments: Theoretical and Regional Policy Issues with Reference to Switzerland." In E. Hein, A. Heise and A. Truger (eds). Finanzpolitik in der Kontroverse. Marburg: Metropolis, 227-250.

Downs, A. 1957. An Economic Theory of Democracy. New York: Harpern and Row.

Epstein, D. and S. O’Halloran. 1999. Delegating Powers: A Transaction Cost Politics Approach to Policy Making Under Separate Powers. Cambridge, New York, Melbourne and Madrid: Cambridge University Press.

Heinelt, H. and N. Hlepas. 2006. “Typologies of Local Government Systems.” In H. Bäck, H. Heinelt and A. Magnier (eds). The European Mayor: Political Leaders in the Changing Context of Local Democracy. Wiesbaden: Verlag für Sozialwissenschaften, $21-42$.

Herczyński, J. and A. Sobotka. 2013. Sieć szkót podstawowych i gimnazjów 2007-2012. Warszawa: IBE.

Hunter F. 1953. Community Power Structure. New York: Anchor Books.

Mouritzen, P. E. and J. Svara. 2002. Leadership in the Apex: Politicians and Administrators in Western Local Governments. Pittsburgh: University of Pittsburgh Press. 
Mouritzen, P. E. and S. Winter. 1992. “Are Voters Naive Egoists?" Paper presented at the ECPR Joint Session of Workshops, Limerick, 30 March-4 April 1992.

Rees, R. 1985. “The Theory of Principal and Agent." Bulletin of Economic Research 37(1-2), p.3-26.

Regulski, J. 2014. "Za dużo góry. Dajmy ludziom rządzić się samym.” Available at http://samorzad.pap.pl/depesze/wiadomosci_centralne/144962/Za-duzogory--Dajmy-ludziom-rzadzic-sie-samym---mowi-prof--Jerzy-Regulski (last accessed 07.06.2015).

Stiglitz, J. E. 1987. "Principal and Agent." In J. Eatwell, M. Millgate, P. Newman (ed.). The New Palgrave Dictionary of Economics, vol. 3. London: Macmillan, p. 966-971.

Stone, C. 1989. Regime Politics: Governing Atlanta 1946-1988. Lawrence: University Press of Kansas.

Swianiewicz, P. 2011. Finanse lokalne: koncepcje, realizacja, polityki lokalne. Warszawa: Municipium.

Swianiewicz, P. and J. Łukomska. 2015. "Local Tax Policies in the Limited Autonomy of Revenue Collection System in Poland." In Junghun Kim, J. Lotz and N. J. Mau (eds). Interaction between Local Expenditure Responsibilities and Local Tax Policy. Copenhagen: The Korea Institute of Public Finance and The Ministry for Economic Affairs and the Interior, 255-280.

Swianiewicz, P. and J. Łukomska. 2014. “Local Tax Competition in Poland?” Paper presented at the Annual NISPAcee conference, Budapest, 22-24 May 2014. 